\title{
Studies on Floral Morphology of Subtropical Plum (Prunus salicina Lindl.)
}

\author{
G. Kour* \\ Department of Horticulture, Faculty of Agriculture, Khalsa Collage, \\ Amritsar, Punjab, India, 143001 \\ *Corresponding author
}

\begin{tabular}{|l|}
\hline Ke y w o r d s \\
Floral morphology, \\
Plum cultivars
\end{tabular}

A B S T R A C T

Being early ripening, low chill plums grown in Indian sub-tropics have the potential for production of quality fruits and plum growing in the plains can be made successful venture by evolving improved varieties. Bearing habit, flower bud development and flower morphology, time and duration of flowering, anthesis, dehiscence, pollen studies (pollen viability and germinabitily) were studied in six varieties. Alu Bokhara Amritsari produced flowers on spurs. Flower bud passed through seven despotic stages and took 23.5 to 29.5 days to complete all the stages of flower bud development. Kala Noki commenced the flowering earliest ( $3^{\text {rd }}$ February). The longest period of flowering (29 days) was recorded in Alu Bokhara Amritsari. Maximum anthesis (30.9- 42.0 to 28.8- 46.0 per cent) in all cultivars was recorded between 12 noon to $2 \mathrm{p}$. $\mathrm{m}$. and dehiscence (7.7 - 31.0 to $5.7-30.9$ per cent) in all cultivars with a peak period between 10 a.m. to 2 p.m. Stigma became receptive one day before anthesis (32 to 28 fruitset) in all the cultivars. Pollen viability was found maximum in Satluj Purple (94.7\%) and sucrose solution of 20 per cent proved most efficacious with regard to pollen germination in all the six cultivars under study. The study undertaken will be useful for taking up plum improvement in subtropics.

\section{Introduction}

The plum is temperate fruit and ranks next to the peaches in economic importance among stone fruits. Among several species which originated in various parts of the world, the Prunus domestica Linn. and Prunus salicina Lindl. are the two most important species from fruit production point of view in the temperate and sub temperate regions. Some low chilling cultivars of Japanese plum are also successfully grown under subtropics-the states of Punjab, Haryana and Uttar Pradesh.
Improvement of plum had been taken up since 1989, by screening the rich indigenous genetic diversity in Punjab - the Indian subtropics, with the objective to select the superior varieties/strains. Extensive exploration were made in the plum growing areas of Punjab state, more diversity has also been reported by Kang et al., (2005) based on characters. Some accession identified, were evaluated for fruit characters, maturity period, bearing and tree vigour etc. the pooled data showed a high range of variability. The maturity period varied from the first week of May to mid June. 
High variability was also observed in tree growth and flowering. On the basis of fruit quality characters and tree longevity, the most promising was the genotype (ASR/BL-2) collected from village Bahila in Amritsar district. The ex situ conservation of this isolated genotype was carried out and propagated plants were planted during 1995 in the experiment orchards of Khalsa Collage and Government orchards Attari to critically examine the genotype in subsequent years.

The selection named as Alu Bokhara Amritsari showed its promise by producing large sized fruits of attractive red colour having high TSS: acid ratio coupled with some special merits like free stone, pink coloured flesh with uniform sweetness and thus is absolutely free from sourness near the pit, the serious most drawbacks of Indian plums (Bal, 2001; 2004). The germplasm of some other elite genotype had also been conserved and is under observation for their future use as donor parents for the attributes of early maturity, high yield and dwarfness etc. such as Kala Amritsari- a local selection and FLA 1-2 by Dhatt et al., (1991) recommended under the name of Satluj Purple (Anonymous, 1999). Satluj Purple a recently high quality plum variety recommended by Punjab Agricultural University, Ludhiana is not selffruitful; hence require the pollinizer Kala Amritsari (Anonymous, 2001) and Alu Bokhara Amritsari- a promising plum, recently reported from Amritsar conditions of Punjab (Bal, 2004), needs to be studied for its flowering behaviour in detail under field conditions (Sandhu, 2002).

If the plum growing in the plains has to make a successful venture, better cultivars have to be evolved by launching a planned breeding programme. The techniques used in plum breeding are similar to those that are used for the other deciduous fruits. These involves introduction, evaluation, selection and release of varieties, further improvement involves pollen collection, emasculation and pollination of flowers from selected parents, seed collection and germination and an evaluation of the progeny. Thus, for a successful breeding programme, a detailed knowledge of the floral morphology of the existing germplasm is a pre-requisite. Hence, there is a dire need to derive information on the floral behaviour of recently reported varieties in the light some other local plum cultivars. This study includes various aspects of flowering viz: bearing habit, flower bud development, time and duration of flowering, anthesis, dehiscence, stigma receptivity and pollen study. It is hoped that the studies will be useful for taking up plum improvement in subtropics.

\section{Materials and Methods}

The investigations on the floral morphology in the six cultivars of plum viz. Satluj Purple, Kala Noki, Dhariwal, Manaka, Gurda, and Alu Bokhara Amritsari were carried in the plum collection block of Khalsa College, Amritsar. Amritsar falls at $31^{\circ}-38^{\prime} \mathrm{N}$ latitude and $74^{\circ}$ $52^{\prime} \mathrm{E}$ longitude at an elevation of $236 \mathrm{~m}$ aMSL. It represents typical sub-tropical climatic conditions prevailing in the central zone of Punjab with an annual rainfall of 735 $\mathrm{mm}$, major portions of which fall during July to September. In summer months of May-June temperature rises to $45^{\circ}$ and even higher on some days, whereas winter is very cold. The plants in this region get nearly 250 to 300 hours of chilling period. The trees were approximately 8 years old and planted at a spacing of four meters plant to plant in rows six meter apart.

\section{Bearing habit}

To study the bearing habit of the plum ten shoots on each tree were marked all around the canopy of the trees and the position of 
flower was observed whether growing terminally or laterally.

\section{Flower bud development and flower morphology}

The development of floral bud was studied from last week of January to the 2nd week of February. A total of forty buds on the four selected trees were examined. The whole phases of bud development were divided into seven stages based upon the shape and colour of the bud. The developmental stages and the number of days required to undergo a change from one stage to another were recorded.

\section{Time and duration of flowering}

In order to find out the time of flowering and duration in each cultivar, four trees per cultivar were marked for observation. Four bearing shoots on each of the trees were tagged in the second week of January and following observations were scheduled: a. date regarding time of flower bud swelling, $b$. opening of the first flower, c. effective blooming period and $\mathrm{d}$. peak period of flowering and its completion were recorded.

\section{Anthesis}

The number of flowers opening between 8 a.m. to 4.00 p.m. was recorded daily for a period of seven days at an interval of two hours. The opened flowers were counted and removed to avoid re-counting.

\section{Dehiscence}

Ten flowers, likely to open next morning, were selected in each cultivar in evening to note the time of dehiscence. This was observed for seven days. As soon as the flowers opened, the total number of anthesis per flower was counted at every two hours interval, starting from 8 a.m. and counting till
6.00 p.m., the number of dehisced anthers was noted.

\section{Stigma receptivity}

\section{a. Visual observation}

The stigmatic surface of flowers was examined with a hand lens. The stigma was taken to be receptive, when it was shining, plump and glossy and with a profuse secretion of stigmatic fluid. Brownish colouration or dry surface was the indication of the non receptive state.

\section{b. Fruit-set method}

The stigma receptivity in all the six cultivars was also tested by recorded fruit-set under controlled pollination. In each case, fifteen to twenty five flowers were emasculated and pollinated at the under mentioned periods: 2 days before anthesis, 1 day before anthesis, on the day of anthesis, 1 day after anthesis, 2 day after anthesis and 3 day after anthesis.

\section{Pollen morphology}

Few pollen grains of each genotype under observation were dusted on to a microscopic slides spread uniformly and covered with a cover slip for studying pollen shape. These slides were examined under the microscope.

\section{a. Pollen viability}

The viability of pollen grains was studied with two per cent acetocarmine solution. Pollen grains from freshly dehisced anthers were placed on the slides and a drop of acetocarmine solution was put on these. The prepared slides were examined under microscopes after a few minutes. The pollen grains, which stained deeply, looked normal and symmetrical were considered as viable and the rest as non-viable. 


\section{b. Pollen germinabitily}

The germination of pollen grains was studied with $5,10,15 \& 20$ per cent sucrose solution. Pollen grains from freshly dehisced anthers were dusted in the cavity of a slide and sufficient sucrose solution was put to fill the cavity.

The cavity was thereafter, covered with a cover slip, the slides so prepared were kept in Petri dishes duly inner-lined with blotting paper and wetted to created an almost saturated atmosphere at room temperature. The germination counts were made after an interval of 24 hours.

\section{Results and Discussion}

\section{Bearing habit}

Satluj Purple, Kala Noki, Gurda, Manaka and Dhariwala bear on one year old shoot. In contrast to these, the variety Alu Bokhara Amritsari produced flower on spurs. The buds generally occurred in three's, the two outer being flower buds and central one as leaf bud. Plum flowers were born mostly on one year old shoots and on spurs (Randhawa and Nair, 1960). Two buds usually appear from each node and are separated from one another by the middle vegetative bud. Similar type of bearing habit was also reported in plum by Sandhu (2002) under Amritsar conditions. Kumar et al., (1994) reported that Frontier plum had more lateral shoots and spur formation whereas Santa Rosa had fewer numbers of lateral shoots resulting in less spur formation.

Flowers of plum were initiated generally before or rarely with leaves in the lateral buds of current season shoots and new growth on older spurs. Two buds usually appear from each node and were separated by the middle vegetative bud (Verma and Jindal, 1997).

\section{Flower bud development and floral morphology}

In all six varieties under investigation, the flower bud development was passed through seven despotic stages (Table 1). Flower bud development completed within 23.5 to 29.5 days in plum cultivars. The difference in days was due to type of cultivars or locality. Randhawa and Nair (1960) stated that flowers of different plum varieties took variable total number of days (16 to 23 days). Contrary to this, Sandhu (2002) stated that time taken for flower bud development in different plum varieties varied from 25 to 28.5 days. Wells and Bukovac (2000) observed flower initiation and differentiation in plum cultivar 'Stanley' and reported that all buds examined between 30 and 50 days after full bloom (DAFB) had conical apices and were considered vegetative. Kumar et al., (2004) reported that the peach cultivars differed in their requirement to complete the bud development and the period varied from 22 days in Early white Giant to 26 days in Crawford. Plum flowers were bracteates, pedicilate, complete, regular and hermaphrodite. The sepals and petals were five, attached in a single whorl. The stamens number varied from 20 to 30 in different cultivars. The anther was two lobed, with different colours i.e. Reddish in Kala Noki and Gurda whereas Satluj Purple, Manaka, Dhariwala and Alu Bokhara Amritsari having yellow and yellowish orange colour. The single carpel was observed in all the six plum genotypes evaluated. Similar type of flower morphology was also reported by Lal (1993) and Kaushal et al., (2004) in plum under Indian conditions.

\section{Time and duration of flowering}

The flowering in cultivars of plum commenced in different time, Kala Noki, Dhariwala and Satluj Purple were earliest to flower on 3rd February, 4th February and 5th February followed by Gurda and Manaka 
which started flowering on 8th and 12th February, whereas Alu Bokhara Amritsari was last to flower in the end of February i.e. on 23rd February (Table 2). The minimum time interval between appearance of first flower and full bloom varied from 6 to 13 days. This may be attributed to the earlier rise of the temperature during present evaluation years (Fig. 1). The finding is in agreement with the previous report of Cooper et al., (1963), while studying the tree growth and fruit quality of 'Valencia' oranges in relation to climate found that the duration of flowering was greatly accelerated or slowed by the climatic conditions. They observed that completion of extension growth and flowering in Valencia orange by 28th March at Orlando, Clemont and Weslaco where warm day and night prevailed as compared to other locations, where completion of extension growth and flowering took place by 15th April because relatively cool days and night prevailed in early spring. Bellini et al., (1992) reported the flowering time in European plum selection between 20th March and 1st April. Aulakh (1994) stated that effective blooming period of plum was recorded 6-12 days under Punjab condition. Plum cultivars showed differences with respect to duration of flowering full blooming periods. The longest full bloom period of 13 days was observed in Alu Bokhara Amritsari and shortest period of 6 days was noticed in Dhariwala. Low chilling plum cultivars show extended bloom, ranging from 10 days to 38 days of flowering. A variation was also seen in date of full bloom. When peach and plum cultivars are grown in areas where their chilling requirement is not met, their bloom period become as long as 2 to 5 weeks and fruit set will be low (Strong and Byrne, 1995). Kemp (1996) observed the flowering time of four plum cultivars in Europe and found that first flower opened from 5th April to 11th May and attained full bloom 12th April to 19th May. Szabo and Nyeki (1996) reported that flowering period varied from 4 to 15 days in different plum cultivars. Contrary to this, Bajwa et al., (1990) who reported that full bloom period varied 9 to 10 days in different plum varieties and Josan et al., (1999) reported that period of full bloom varied from 8 February to 23 March among the plum cultivars. Szabo and Nyeki (2002) reported that Japanese plum started blooming earlier by one week than the European plums as a mean of many years and on all growing sites observed in Hungry. The blooming period of varieties overlapped each other at a rate of more than $67 \%$. The longest duration of flowering of 29 days was observed in Alu Bokhara Amritsari and Dhariwala recorded the lowest duration of 19 days. The longest duration of flowering in Alu Bokhara Amritsari might be to more irrigation provided as it flowering commenced during March (March onwards till September, the climate is hot and dry under subtropical regions and maximum irrigation is required during this period) and lowest in Dhariwala due to less water. Josan et al., (1999) also reported flowering duration of 29 to 43 days in different plum varieties. Generally, the difference in duration of flowering can also be referred to varietals behaviour of different plum varieties. Similar observation on start of flowering, end of flowering and full bloom, and flowering duration in different varieties of plum have been well documented by Bajwa et al., (1990). According to present study the commencement of the flowering in Alu Bokhara Amritsari was recorded on 23rd February, is quite earlier than the study conducted by Sandhu (2002). The time of flowering varied from first week of February to first week of March and showed duration of as short as 14 days to as long as 31 days. The time and duration of flowering is considered more or less a shifting event depending on season, age, vigor of the plant besides the extent of winter chilling to break the rest followed by warm temperature (Kang et al., 2005) 


\section{Anthesis and Dehiscence}

During the course of investigation, there was no anthesis till 8.00 a.m. which started fast during the spell 8.00 a.m. to 10.00 a.m. The anthesis picked up the momentum very fast during 12.00 to $14.00 \mathrm{p} . \mathrm{m}$. to the tune of 30.9$42.0,32.0$ - 42.2, 31.8 - 40.7, 30.3 - 44.2, 27.5 - 45.3 and 28.8 - 46.0 per cent in Kala Noki, Satluj Purple, Dhariwala, Manaka, Gurda and Alu Bokhara Amritsari (Fig. 2a). The anthesis again followed slight slowdown during 14 to 16 p.m. and completely declined during 18.00 p.m. onwards. Anthesis in all the six cultivars took place slowly in two to three days; it may be referred to type varietals behaviour as well as increasing temperature during noon. Bhandal (1982) observed that maximum anthesis occurred from 8.00 a.m. to 4.00 p.m. in all the three plum cultivars under study i.e. Kala Amritsari, Alu Bokhara and Lalri. Anthesis in plum took place slowly and about two days required for completion of anthesis and flowers remained open for about 2-3 days till the petals were shed. Anthesis started at $8.00 \mathrm{hrs}$ and continued till $18.00 \mathrm{hrs}$ (Verma and Jindal, 1997). The dehiscence starts from the inner whorls to the outer whorl. The dehiscence started after 4-5 hours of the flower opening in Alu Bokhara Amritsari and Dhariwala (Fig. 2b).

Table.1 Average number of days required for passing through each stage

\begin{tabular}{|c|c|c|c|c|c|c|c|c|c|}
\hline Cultivars & $\begin{array}{l}\text { No. of buds } \\
\text { observed }\end{array}$ & $\begin{array}{l}1^{\text {st }} \\
2^{\text {nd }}\end{array}$ & $\begin{array}{l}2^{\text {nd }} \\
3^{\text {rd }}\end{array}$ & $3^{\text {rd }}$ & $\begin{array}{l}4^{\text {th }} \\
5^{\text {th }}\end{array}$ & $\begin{array}{l}5^{\text {th }} \\
6^{\text {th }}\end{array}$ & $\begin{array}{l}6^{\text {th }} \\
7^{\text {th }}\end{array}$ & $\begin{array}{l}7^{\text {th }} \\
\text { Full } \\
\text { bloom }\end{array}$ & $\begin{array}{l}\text { Total } \\
\text { number of } \\
\text { days }\end{array}$ \\
\hline 1. Dhariwala & 40 & 5 & 5 & 4 & 4 & 2.5 & 4 & 1 & 23.5 \\
\hline 2. Satluj Purple & 40 & 5 & 5 & 4.5 & 4 & 2.5 & 4 & 1 & 26 \\
\hline 3. Gurda & 40 & 5 & 4 & 4 & 4 & 4.5 & 3.5 & 1 & 26 \\
\hline 4. Kala Noki & 40 & 5 & 4 & 4.5 & 5 & 4 & 4 & 1 & 27.5 \\
\hline 5. Manaka & 40 & 4 & 6 & 6 & 4.5 & 4 & 2.5 & 1 & 28 \\
\hline $\begin{array}{l}\text { 6. Alu Bokhara } \\
\text { Amritsari }\end{array}$ & 40 & 7 & 5 & 6 & 4 & 2.5 & 4 & 1 & 29.5 \\
\hline
\end{tabular}

Table.2 Time and duration of flowering

\begin{tabular}{|l|l|l|l|l|l|l|}
\hline Cultivars & First & \multicolumn{2}{|c|}{ Full bloom } & FB* & LF* opened & $\begin{array}{l}\text { Total } \\
\text { duration }\end{array}$ \\
\cline { 3 - 6 } & Flower & Start & End & duration & & \\
\hline 1.Kala Noki & $3^{\text {rd }} \mathrm{F}^{*}$ & $9^{\text {th }} \mathrm{F}$ & $19^{\text {th }} \mathrm{F}$ & 10 days & $24^{\text {th }} \mathrm{F}$ & 22 days \\
\hline 2. Dhariwala & $4^{\text {th }} \mathrm{F}$ & $11^{\text {th }} \mathrm{F}$ & $17^{\text {th }} \mathrm{F}$ & 6 days & $22^{\text {nd }} \mathrm{F}$ & 19 days \\
\hline 3. Satluj Purple & $5^{\text {th }} \mathrm{F}$ & $11^{\text {th }} \mathrm{F}$ & $20^{\text {th }} \mathrm{F}$ & 9 days & $28^{\text {th }} \mathrm{F}$ & 24 days \\
\hline 4. Gurda & $8^{\text {th }} \mathrm{F}$ & $15^{\text {th }} \mathrm{F}$ & $25^{\text {th }} \mathrm{F}$ & 10 days & $4^{\text {th }} \mathrm{M}^{*}$ & 25 days \\
\hline 5. Manaka & $12^{\text {th }} \mathrm{F}$ & $17^{\text {th }} \mathrm{F}$ & $26^{\text {th }} \mathrm{F}$ & 9 days & $6^{\text {th }} \mathrm{M}$ & 23 days \\
\hline 6. Alu Bokhara Amritsari & $23^{\text {rd }} \mathrm{F}$ & $5^{\text {th }} \mathrm{M}^{*}$ & $18^{\text {th }} \mathrm{M}$ & 13 days & $25^{\text {th }} \mathrm{M}$ & 29 days \\
\hline
\end{tabular}

*FB - Full Bloom, "LF- Last flower,*F-February, *M -March 
Table.3 Stigma receptivity by fruit set method in plum cultivars

\begin{tabular}{|c|c|c|c|c|c|c|}
\hline \multirow[t]{2}{*}{ Crosses } & \multicolumn{6}{|c|}{ Time of pollination and emasculated/pollinated buds } \\
\hline & $\begin{array}{l}2 \text { days* } \\
\text { (15) }\end{array}$ & $\begin{array}{c}1 \text { day* } \\
\text { (15) }\end{array}$ & $\begin{array}{l}\text { On the day } \\
\text { (25) }\end{array}$ & $\begin{array}{l}1 \text { day*** } \\
\text { (25) }\end{array}$ & $\begin{array}{c}2 \text { days*** } \\
\text { (25) }\end{array}$ & $\begin{array}{c}3 \text { days*** } \\
\text { (25) }\end{array}$ \\
\hline${ }^{1} \mathrm{KN}$ x SP & 0 & 26.7 & 32 & 20 & 20 & 16 \\
\hline${ }^{2} \mathrm{SP} \times \mathrm{KN}$ & 0 & 20 & 32 & 16 & 16 & 8 \\
\hline${ }^{3} \mathrm{G} \times \mathrm{D}$ & 0 & 26.7 & 28 & 20 & 16 & 12 \\
\hline${ }^{4} \mathrm{G} \times \mathrm{G}$ & 0 & 20 & 28 & 20 & 16 & 8 \\
\hline${ }^{5} \mathrm{M} \times \mathrm{M}$ & 0 & 13.4 & 20 & 16 & 12 & 8 \\
\hline${ }^{6} \mathrm{AB} \times \mathrm{AB}$ & 0 & 20 & 28 & 24 & 20 & 12 \\
\hline
\end{tabular}

* Before anthesis, ** after anthesis, ${ }^{1}$ Kala Noki x Satluj purple, ${ }^{2}$ Satluj Purple x Kala Noki, ${ }^{3}$ Gurda x Dhariwala,

${ }^{4}$ Gurda x Gurda, ${ }^{5}$ Manaka x Manaka, ${ }^{6}$ Alu Bokhara Amritsari x Alu Bokhara Amritsari

Table.4 Pollen viability test in six plum varieties

\begin{tabular}{|l|c|c|c|c|}
\hline Cultivars & $\begin{array}{c}\text { Total no. of pollen } \\
\text { grains examined }\end{array}$ & \multicolumn{2}{|c|}{$\begin{array}{c}\text { No. of pollen grains } \\
\text { Viable }\end{array}$} & $\begin{array}{c}\text { Percentage } \\
\text { of viability }\end{array}$ \\
\hline 1. Satluj Purple & 96 & 91 & 5 & $94.7 \%$ \\
\hline 2. Kala Noki & 154 & 134 & 20 & $87.0 \%$ \\
\hline 3. Manaka & 163 & 135 & 28 & $84.6 \%$ \\
\hline 4. Alu Bokhara Amritsari & 126 & 103 & 23 & $81.7 \%$ \\
\hline 5. Dhariwala & 52 & 42 & 10 & $80.7 \%$ \\
\hline 6. Gurda & 134 & 108 & 26 & $80.5 \%$ \\
\hline
\end{tabular}

Table.5 Pollen germination test at different percent sucrose solution in six plums

\begin{tabular}{|l|c|c|c|c|}
\hline \multirow{2}{*}{ Cultivars } & \multicolumn{4}{|c|}{ Percentage (\%) of germination at } \\
\cline { 2 - 5 } & $\mathbf{5 \%}$ & $\mathbf{1 0 \%}$ & $\mathbf{1 5 \%}$ & $\mathbf{2 0 \%}$ \\
\hline 1. Satluj Purple & 57.4 & 59.8 & 62.5 & 64.1 \\
\hline 2. Kala Noki & 56.4 & 59.6 & 61.1 & 62.6 \\
\hline 3. Gurda & 48.7 & 51.8 & 54.5 & 61.9 \\
\hline 4. Alu Bokhara Amritsari & 54.5 & 56.3 & 58.8 & 60.3 \\
\hline 5. Dhariwala & 49.3 & 52.9 & 56.5 & 59.5 \\
\hline 6. Manaka & 53.1 & 58.8 & 60.3 & 58.9 \\
\hline Average germination & $\mathbf{5 3 . 2}$ & $\mathbf{5 6 . 6}$ & $\mathbf{5 8 . 9}$ & $\mathbf{6 1 . 2}$ \\
\hline
\end{tabular}


Fig.1 Climatic conditions during flowering

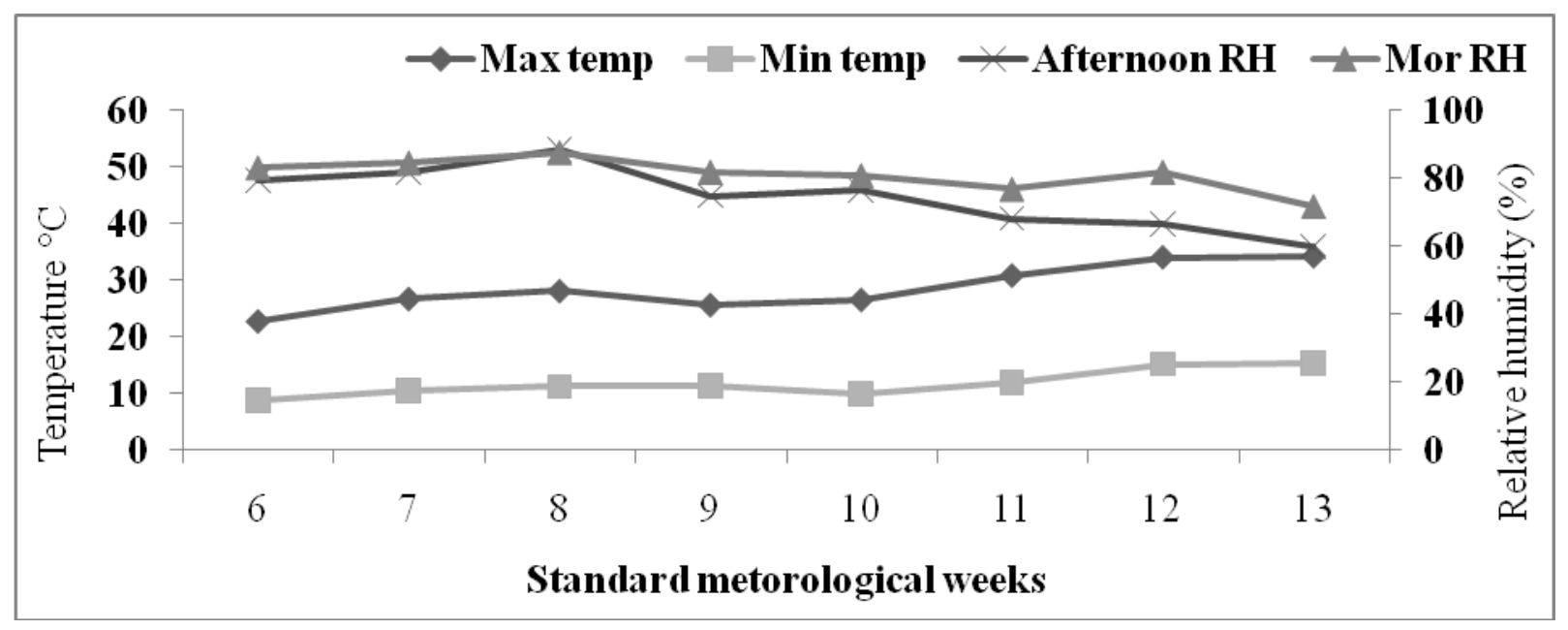

Fig.2 a) Anthesis in six plum cultivars \& b) Dehiscence in six plum cultivars
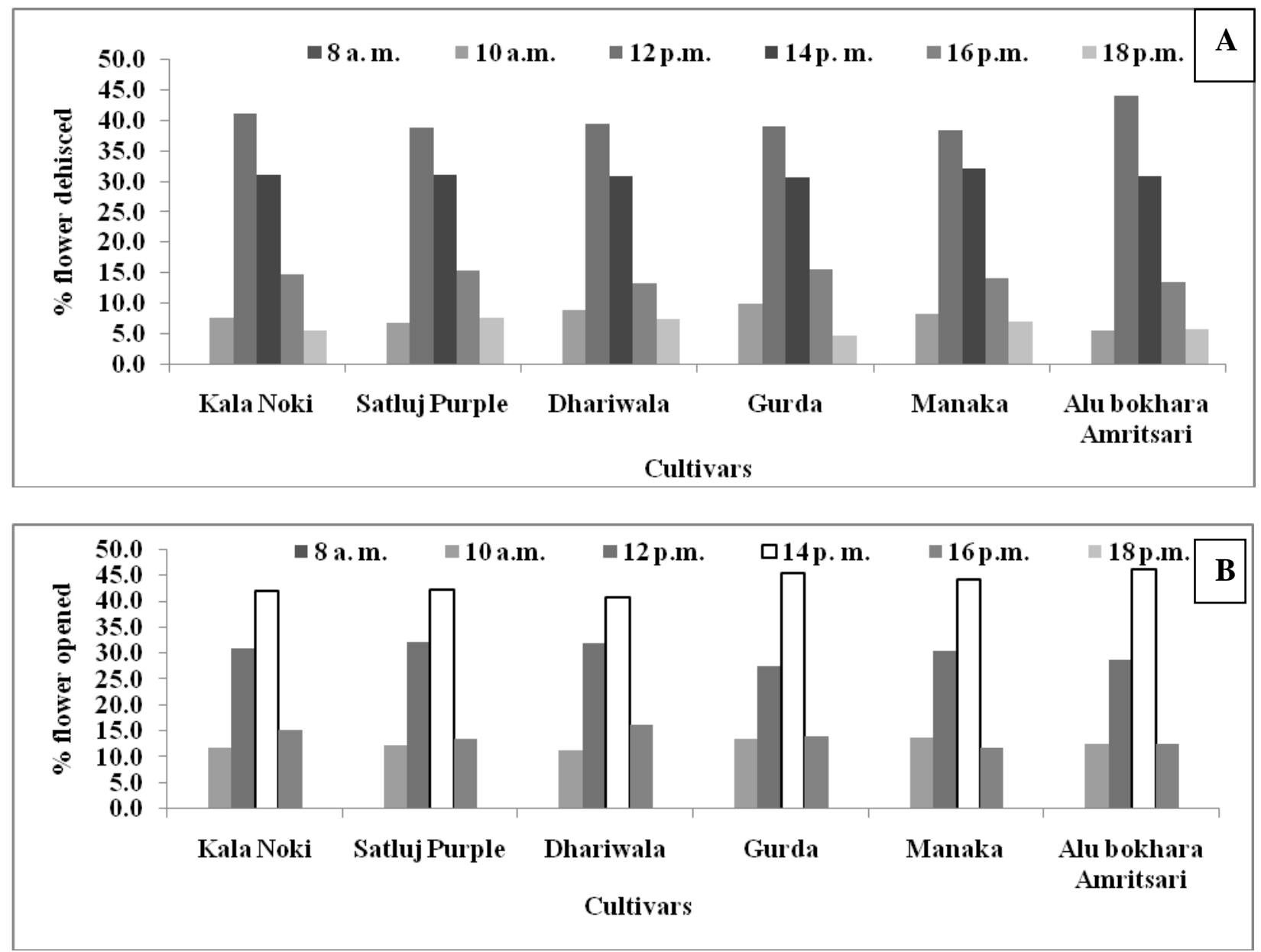
The dehiscence in Manaka, Kala Noki, Gurda and Satluj Purple started after complete opening of flower. This difference can be attributed to varietals behaviour. The dehiscence of anthers occurred throughout the day with maximum dehiscence between 10.00 a.m. to 2.00 p.m. to the tune of $7.7-31.0,6.9$ - 31.1, 9.0 - 30.9, 8.3 - 32.0, 9.9 - 30.7 and 5.7 - 30.9 per cent in Kala Noki, Satluj Purple, Dhariwala, Manaka, Gurda and Alu Bokhara Amritsari depending on the temperature of the day. The high temperature and low humidity seemed to hasten the dehiscence of anthers. Similarly, Nyeki and Szabo (1995) reported that in Prunus domestica and Prunus salicina the anther dehiscence was more sensitive to changing temperature. Singh et al., (2004) observed that anthers dehisced abruptly between 12.00 15.00 hrs. in all the cultivars of pear and continued for 3 to 4 hours after opening.

It was further observed that maximum proportion of anther dehiscence was recorded between 12.00-14.00 hours in all the cultivars due to fact that temperature during these hours were usually higher and fall in humidity during that period may also have accelerated the dehiscing process.

\section{Stigma receptivity}

The stigma was considered to be receptive when it showed secretion like fluid on it. Stigma in all the six plum cultivars found to become receptive one day before anthesis. Stigma remained in a receptive condition three days after anthesis with maximum receptivity on the day of anthesis.

All the six plum genotypes behaved similarly. The receptivity of stigma was also observed by actual fruit set method. Stigmas of emasculated flowers at different stages were control pollinated. Fruit set was observed after twelve days of pollination (Table 3). The maximum stigma receptivity by fruit set method was observed in six plum cultivars ranged from 20 to 30 per cent fruit set on the day of anthesis. The stigma was found not receptive two days before anthesis in all the cultivars.

Bajwa et al., (1990) observed that in plum stigma becomes receptive one day before anthesis and remained so up to three days after anthesis whereas stigma receptivity is maintained upto a maximum of 6 days after anthesis (Lee and Bunemann, 1981). Nyeki and Szabo (1995) observed that temperature had a significant effect on stigma longevity. Stigma longevity was 3-5 days in Prunus domestica and 2-4 days in Prunus salicina when the average daily temperature was less than $10^{\circ} \mathrm{C}$. It was less when average daily temperature was greater than $13^{\circ} \mathrm{C}$. Kumar and Sharma (1997) reported that in plum, stigma remained receptive from one day before anthesis to two days after anthesis.

\section{Pollen Morphology}

\section{Pollen viability and germinabitily}

In the present study, highest pollen viability of 94.7 per cent in Satluj Purple and lowest 80.5 per cent in Gurda may be due to climatic conditions of the location as well as varietals behavior (Table 4). The results of the investigations are in conformity with the results obtained by Gercekcioglu et al., (2000) who reported that pollen viability ranged from 71.53-81.78 per cent in stone fruit cultivars (plum) and Sharma and Bist (2003) who observed pollen viability range from 77.08 to 93.05 per cent in different varieties under Himachal Pradesh (India) conditions. Kumar et al., (2004) studied the lowest pollen viability in Crawford Early 74.90 per cent and 94.22 per cent highest viability in Early White Giant peach. Further, found highest pollen germination (61.2 per cent) in 20 per cent sucrose solution followed 
by 58.9 per cent to 56.6 per cent in 15 per cent and 10 per cent sucrose solution (Table 5). The highest pollen germination $38.4 \%$ was found in Santa Rosa and lowest 23.0 per cent in Formosa (Chung et al., 1998). Similar reports have been reported by Sandhu (2002) and Bal and Nandan (2013) in plum varieties in 15 and 20 per cent sucrose solution, whereas Shaoling (2003) reported 60 to 90 per cent pollen germination rate in 10 per cent sucrose solution. Sharma and Bist (2003) observed maximum germination of pollen grains in 15 per cent sucrose solution +10 ppm boric acid, whereas Kumar et al., (2004) recorded the high pollen germinabitily in 10 and 15 per cent sucrose solution in July Elberta peach.

\section{References}

Anonymous. 1999. Package of practices for cultivation of vegetables, mushrooms, flowers and fruits, Punjab Agricultural University, Ludhiana, 124-128p.

Anonymous. 2001. Area and production of fruits in Punjab, Directorate of Horticulture, Punjab, India.

Aulakh, P.S. 1994. Time and flowering in different cultivars of plum (Prunus salicina Lindl.) grown under the arid irrigated conditions of Punjab, a note. Punjab J. Hort., 34(3-4): 81-83.

Bajwa, G.S., A.S. Bindra, J.S. Bal, and P.P.S. Minhas, 1990. Problems of pollination and fertilization in plum. Acta Hort., 283: $157-162$.

Bal, J.S. 2001. Performance of Alu Bokhara Amritsari a new variety of plum for subtropics. J. Plant Gen. Res., 14(1):236-237.

Bal, J.S. 2004. Genetic resource of plum under sub tropical condition of Punjab. Acta Hortic, 662:147-149.

Bal, J.S. and R. Nandan, 2013. Pollen Morphology of some selected plum genotype in the sub-tropics. Acta Hortic, 985: 57-63.

Bellini, E., E. Giordani and V. Nencetti, 1992. Behaviour of new early plum selection grafted on two rootstocks. Acta Hortic., 317:133-139.

Bhandal, T.S. 1982. Studies on floral biology of plum. M.Sc. Thesis submitted to Guru Nanak Dev University, Amritsar.

Chung, K.H., J.H. Jun, and S. Kang, 1998. Selection of suitable pollinizers for major Japanese plums. Korean Society J. Hort. Sci., 39 (5): 560-563.

Cooper, W.C.A., J.R. Peynado, R.H. Furr, G.A.C. Hilgeman and S.B. Boswell, 1963. Tree growth and fruit quality of Valencia oranges in relation to climate. J. Am. Soc. Hort. Sci., 82: 180 $-192$.

Dhatt, A.S., Y.R. Chanana, G.S. Nijjar, P.P.S. Minhas, A.S. Dhillon and D.K. Uppal, 1991. FLA 1-2, a new variety of plum. J. Res. P A U, 28: 152.

Gercekcioglu, R. M. Gunes and Y. Ozkan, 2000. A study on determination of pollen quality and pollen production of some fruit cultivars grown in Tokat ecological conditions. Bahce, 29(1/2): 57-64.

Josan, J.S., J.N. Sharma, N.K. Mehrotra and P.K. Monga, 1999. Performance of some plum cultivars under arid irrigated region of Punjab. Indian J. Hort., 56 (4): 299-303.

Kang, H.S, J.S. Randhawa and G.S. Cheema, 2005. Evaluation of biodiversity in subtropical plums. Acta Hort., 696:5759.

Kaushal, R., P. Parmar, S.D. Sharam and H.S. Bist, 2004. Floral morphology and flowering studies in some plum and apricot cultivars. Indian J. Hort., 61(3): 276-277. 
Kemp, H. 1996. Flowering phenology in European countries apples, pear, plum and cherry. Acta Hort., 423:299-302.

Kumar, J.R., L. Sharma and H.S. Verma, 1994. Performance of new plum cultivars- Frontier. Haryana J. Hort. Sci., 28(1\&2):27-29.

Kumar, K. and S.D. Sharma, 1997. Breeding habit and floral biology of fruit and nut crops. Elementary fruit Breeding, pp: 42-44.

Kumar, N., D.C. Dimri, and J.K. Nigma, 2004. Studies on flowering, fruit set and growth pattern of some promising peach cultivars grown under humid temperate mid hills of Uttaranchal. India J. Hort., 61 (3):271-272.

Lal, R. 1993. Studies on taxonomy and cytology of some plum cultivars, Dr. Y. S. Parmar University of Horticulture and Forestry, NauniSolan, India, Thesis.

Lee, C.L. and G. Bunemann, 1981. Pollen germination, pollen tube growth and fertilization behavior in Prunus domestica, II. Fertilization behavior of some plum cultivars. Gartenbauwissenschaft 46 (5): 217 223.

Nyeki, J. and Z. Szabo, 1995. Longevity of sexual organs of European and Japanese plum varieties. Acta Agron. Hun., 43(1-2):145-51.

Randhawa, G.S. and P.K.R. Nair, 1960. Studies on floral biology of plum grown under sub tropical conditions. I. Flowering habit, flowering season bud development and sex ratio in flowers. II. Anthesis, dehiscence, pollen studies and receptivity of stigma. Indian $J$. Hort., 17 (1-8): 83-95.

Sandhu, D.S. 2002. Study on the floral biology of sub-tropical plum (Prunus Salicina Lindl.), Guru Nanak Dev University, Amritsar, Punjab, thesis.

Shaolong, Z.X., Chen Dixin, Gao, FY Yong, Zhang, S.L, Xie, W.N., Chen, D.X. and F.Y. Gao, 2003. The variation in pollen content, pollen germination and tube growth among eight species of fruit trees. Acta Agri. Shang., 19(3): 67-69.

Sharma, V.K. and H.S. Bist, 2003.Studies on flower and pollen characteristics in some new introduction of plum. Ann. Agri. Res., 24(1): 40-44.

Singh, S.K., L.D. Bist, and V.B. Patel, 2004. Flowering and floral biology studies in low chill pear cultivars. Indian $J$. Hort., 61(1): 94-96.

Strong, K.J. and D.H. Byrne, 1995. Performance of low chill Japanese plums in subtropical plum Texas. Subtrops Plant Sci, 47:30-33.

Szabo, Z. and J. Nyeki, 1996. Fruit set of plum cultivars under Hungarian Ecological conditions. Acta Hortic., 423: 185-191.

Szabo, Z. and J. Nyeki, 2002. Japanese plum in Hungry. Acta Hortic., 577: 65-68.

Verma, L.R. and K.K. Jindal, 1997. Fruit crops pollinations. Kalyanai Publishers, Ludhiana, India.

Wells, J.M. and M.J. Bukovac, 2000.Flowering and fruiting characteristics of 'Stanley' plum. Acta Hort., 527: 199-204.

\section{How to cite this article:}

Kour, G. 2018. Studies on Floral Morphology of Subtropical Plum (Prunus salicina Lindl.). Int.J.Curr.Microbiol.App.Sci. 7(08): 801-811. doi: https://doi.org/10.20546/ijcmas.2018.708.090 